\title{
The multidimensional attitudes scale towards persons with disabilities (MAS) - a Polish adaptation (MAS-PL)
}

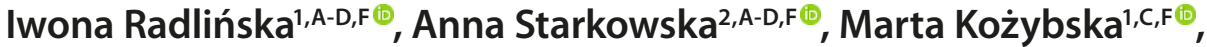 \\ Kinga Flaga-Gieruszyńska, ${ }^{1, \mathrm{E}-\mathrm{F}}$, Beata Karakiewicz ${ }^{3, \mathrm{E}-\mathrm{F} \oplus}$

\begin{abstract}
1 Division of Medical Law, Department of Social Medicine, Pomeranian Medical University in Szczecin, Szczecin, Poland
${ }^{2}$ Faculty of Psychology, SWPS University of Social Sciences and Humanities, Wroclaw, Poland

${ }^{3}$ Division of Public Health and Social Medicine, Department of Social Medicine, Pomeranian Medical University in

Szczecin, Szczecin, Poland

A - Research concept and design, B - Collection and/or assembly of data, C - Data analysis and interpretation,

$D$ - Writing the article, E-Critical revision of the article, F - Final approval of article
\end{abstract}

Radlińska I, Starkowska A, Kożybska M, Flaga-Gieruszyńska K, Karakiewicz B. The multidimensional attitudes scale towards persons with disabilities (MAS) - a Polish adaptation (MAS-PL). Ann Agric Environ Med. 2020; 27(4): 613-620. doi: 10.26444/aaem/114531

\begin{abstract}
Objective. The aim of this study was to create a Polish adaptation of the Multidimensional Attitudes Scale toward Persons with Disabilities (MAS) by performing a statistical psychometric analysis in a sample of Polish students.

Materials and method. The study included 540 person ( $82.0 \%$ of students and $18.0 \%$ of workers), whose attitudes towards the disabled were measured with the Polish version of the MAS (MAS-PL). Mean age of respondents was 24.72 years (SD = 5.7), with a significant majority of women $(n=455,84.3 \%)$. Data was collected during university classes and via an online survey.

Results. Factor analysis yielded a three-factor structure of the MAS-PL, including affective, cognitive, and behavioural domains, which explained almost $45 \%$ of the total variance. Further factor-based solutions increased this percentage only slightly (0.8).

Conclusions. The Polish version of the MAS scale (MAS-PL) has been developed and presented as a reliable instrument for studying the attitudes of Poles towards people with disabilities. The scale can be used as a preliminary assessment tool when creating educational programmes, including those for training and social Policy, as well as assessing the effectiveness of programmes. Studies with the use of the MAS-PL will allow comparisons of research findings conducted with the use of MAS scales in other English-speaking (original/English MAS) or Spanish-speaking (Spanish MAS) populations and German (G-MAS), Korean (MAS-K), Serbian (Serbian MAS), Turkish (Turkish MAS) and French populations (French MAS autism).
\end{abstract}

\section{Key words}

disability, attitudes, measurement scale

\section{INTRODUCTION}

Due to increased exposure to discrimination and social exclusion, persons with disabilities (PWD) are subject to broad legal protection [1]. The reason for this is the widespread negative attitude towards PWD deeply grounded in societies [2]. It is estimated that there are over one billion people with some disability in the world [3]. According to the official estimates, about 4.7 million of them live in Poland [4]. This indicates the high significance of the problems of this population that consist primarily of serious difficulties in undertaking social activity, i.e., education, work, entertainment.

Global findings from the 1960s (Europe) and the 1970s (United States) assumed that the main problem of the PWD social functioning was rooted in their negative social perception (a label, stigma) leading to social exclusion (isolation, sadness, lack of happiness) $[5,6,7,8]$. At the same time, the disabled themselves expressed their poor

Address for correspondence: Marta Kożybska, Department of Medical Law of the Social Medicine Chair, Pomeranian Medical University in Szczecin, Szczecin, Żołnierska 48, 71-210, Poland

E-mail:marta8@pum.edu.pl

Received: 20.06.2019; accepted: 22.11.2019; first published: 10.02.2020 social situation by joining the wave of different social movements created in the USA in the 1960s. During mass protests or demonstrations they demanded more rights and simultaneously objected to being treated only as passive individuals in need of help. The same postulates were implemented in the policies of non-government organizations (NGOs), a approach soon to be called identity policy $[9,10]$.

Since it proved impossible to ignore the above-mentioned social activities, regulations protecting the rights of the disabled appeared in international political and legal documents, the most important being the Standard Rules on the Equalization of Opportunities for Persons with Disabilities, issued by the UN in 1993 [11]. Finally, an innovative social model of disability was defined in the international UN Convention on the Rights of Persons with Disabilities of 13 December 2006 (CRPWD) [12], signed by all EU member states. The Preamble of the CRPWD states that disability is an evolving concept that results from the interaction between persons with long-term impairments (physical, mental, intellectual or sensory) and attitudinal and environmental barriers that hinders their full and effective participation in society as equals with other citizens. All signatory states of the CRPWD [12] are obliged to eliminate such barriers. While the elimination of environmental or 
organizational barriers is relatively easy to enforce, it is much more difficult to change social attitudes toward disability, especially in individual people.

An attitude is one of the most fundamental concepts in social psychology. It seems fairly obvious that one's actions are simply a result of what they think or feel. Therefore, in order to induce positive human behaviour, it is necessary to influence what they think and how they feel, and thus how they intend to act. Hence, an attitude is defined as a structure composed of three elements: the affective (or emotional) aspect (i.e. feelings, emotions related to the object of the attitude), the cognitive aspect (thoughts, knowledge and beliefs related to the object of the attitude) and the behavioural aspect (otherwise known as motivational, including declared or intended behavior / actions toward the object of the attitude) $[13,14,15]$.

The signatory states of CRPWD have an obligation to influence the change of negative social attitudes by raising public awareness of disability, and combating stereotypes or prejudices through information campaigns or creating a positive image of PWD (CRPWD art. 8). Unfortunately, negative attitudes toward PWD remain prevalent in western countries despite decades of inclusion policy and law [16].

Research indicates a need for separate education of various social groups (children, teachers, employers, medical specialists [8] especially in 'disability awareness training' which may increase positive attitudes [17, 18]. Effective information and education activities require proper evaluation of attitudes toward PWD, which is possible with the help of specially designed assessment tools, several dozen of which are currently available [13, 15-23]. Researchers worldwide are investigating these attitudes with recognized questionnaires of confirmed validity and reliability measures, subjected to various validation processes with the consent of their authors.

In Poland, no studies have been conducted so far on any scale designed to assess attitudes towards people with disabilities irrespective of their type, which would be recognized and applied in international research, enabling comparison of results. In the 1960s, Dr. HE Yuker created the best known scale - Attitudes Toward Disabled Persons scale (ATDP), which has been and translated into several dozen languages [24]. However, in time, it turned out that there is a need to create more multidimensional tools to study the attitudes of individual social groups. Based on a research review $[13,15,20-23]$, it was concluded that the Multidimensional Attitudes Scale Toward Persons With Disabilities (MAS) created by Findler, Vilchinsky and Werner [13] is a recognized, multidimensional tool enabling support instrument design, as well as implementation of educational initiatives to improve attitudes towards people with disabilities in all social groups and for all disability types [21]. The MAS corresponds to the tripartite model of attitude [25], designed to measure their affective, cognitive and behavioural components. It was considered to have good overall utility due to its excellent internal consistency and good validity. The tool's concurrent validity was tested against the ATDP scale (affective and behavioural domains) [23].

\section{OBJECTIVE}

The first aim of the study was to obtain the consent of the relevant authors to carry out the adaptation process, carry out the translation tool, and a pilot study to provide data to verify its basic psychometric properties in the Polish population. Comparison of the Polish MAS with the original scale was undertaken by performing statistical psychometric analysis.

\section{MATERIALS AND METHOD}

Procedure. Having identified the need for such assessment tools in Poland, potential instruments were reviewed and the MAS selected as the most appropriate scale. In March 2017, upon e-mail contact with the toll's first author, permission was obtained to start the adaptation process, together with all the necessary materials.

Due to the linguistic simplicity of the questionnaire, its translation into Polish was conducted by the Polish version's first author. When creating the translation, the authors attempted to maintain equivalence with the original text in terms of graphics (façade equivalence) and, above all, with the function it was to fulfill (functional equivalence) to assess attitudes towards PWD in terms of declared emotions, behaviours and beliefs. First, the identical graphical form of the original MAS scale was used, and thus full façade equivalence was maintained. Next, in order to approve the Polish translation, a focus group was established, including clinical psychologists and medical university teachers, who used English in their scientific and didactic endeavours. During the meeting, the panel of experts compared the Polish translations with the original version, and the use of words in the context of research objectives was discussed to maintain functional equivalence. Alternative versions of certain words and phrases were presented, and the panel selected those that were considered the most appropriate or proposed brand new terms - all decisions were made unanimously. After all discussed corrections were made by the first author, the final version of the Polish scale was approved by the appointed experts.

It was decided to dispense with the services of professional translators for several reasons. First of all, the knowledge of English by both the researcher and the expert panel was sufficient to translate this linguistically simple questionnaire. In addition, possible language difficulties could occur considering only the deeper meaning of words and their use in terms of achieving specific research goals, or in connection to the Polish cultural background. Therefore, such problems were not to be solved by translators, but rather by experts in the field (i.e. panel psychologists). Next, the basic psychometric characteristics of the MAS-PL were tested on a Polish sample of 408 students. Having completed the project, the effects were sent to the authors for final acceptance in March 2019.

Instrument. In the study a short socio-demographic survey was used, collecting data such as: age, gender, place of residence, university major, and year of study, and the Polish version of the MAS (MAS-PL).

The structure of the MAS-PL (see Appendix) corresponds to the original MAS scale by Findler, Vilchynski and Werner [13], which is a tool measuring attitudes of the general 
population. The scale consists of 3 subscales corresponding to the 3 components of attitudes: emotional, cognitive and behavioural domains, including a total of 34 items. Each subscale of this self-report instrument contains a list of emotions (16 items), ideas and beliefs (10 items) and declared behaviors ( 8 items). The MAS scale begins with a vignette and description of a scenario of an accidental and forced by circumstances meeting in a cafe of a fully-abled person (Joseph / Michelle) with a person in a wheelchair (male/ female). The respondent is to imagine this situation and indicate the emotions, thoughts and potential behaviours it can elicit in non-disabled people (in the plural). Therefore, the questions are not addressed to the respondent directly, but based on a projection mechanism ensuring greater honesty of the answers [13]. The social scenario vignette was applied to have respondents project their own emotions, thoughts, and behaviours onto the given situation. In addition, this modular instrument, which employs a concrete real-life scenario, could be adapted to apply to a variety of situations and disabilities [13].

In order to facilitate the respondent's thorough understanding of the roles played by the persons mentioned in the scenario, the names of the non-disabled person in the MAS-PL vignette were changed to names that are more popular in Poland (Adam/Ewa), and no personal pronouns ('he'/'she') were used, referring to the characters as 'Adam'/'Ewa' and 'wheelchair user' throughout the form (at the beginning it was explained that the wheelchair user was either a man or a woman). The answers are provided on a 5-point Likert scale, where 1 means 'not at all' and 5 'very much'. Higher scores represent more negative attitudes, and positive items require reverse scoring.

During translation, especially in the case of emotional indices, all potential cultural differences were considered (and consulted with fellow psychologists).

In the cognitions subscale, the term 'OK person' was avoided because despite the fact that the expression 'OK' is widely used in the Polish language when referring to a person, the more natural thing to say is 'he'/'she is fine'.

Study participants. The study involved 540 people aged 19 - 60, mostly students $(81.0 \%, \mathrm{n}=443) .408$ students $(75.6 \%$ of the group) participated in the direct study, while 132 people $(24.4 \%)$ participated in the on-line follow-up study. The full socio-demographic characteristics of the group are presented in Table 1.

Statistical analysis. Statistical analysis was carried out with the IBM SPSS Statistics v. 25 package. In order to assess the structure of the Polish version of the MAS scale, the Principal Components Factor Analysis and Varimax rotation with Kaiser normalisation were performed, while the reliability of the tool and its subscales were evaluated using Cronbach's alpha. The relationships between individual MAS scales and selected socio-demographic variables were determined by pairwise correlations with the Spearman rho coefficient, while gender differences were tested with the non-parametric Mann-Whitney U test. The normality of distributions was verified with the Shapiro-Wilk test. Statistical significance was set at $\mathrm{p}<0.05$, while $\mathrm{p}<0.1$ was considered to indicate a not fully significant statistical tendency.
Table 1. Socio-demographic characteristics of the sample $(N=540)$

\begin{tabular}{lcc}
\hline Variable & M / N & SD / \\
\hline Age & 24.72 & 5.73 \\
\hline Gender & & \\
\hline Female & 455 & 84.3 \\
\hline Male & 85 & 15.7 \\
\hline Place of residence & & \\
\hline Rural areas & 74 & 13.7 \\
\hline Small town & 125 & 23.1 \\
\hline City & 341 & 63.1 \\
\hline
\end{tabular}

Status on the labour market

\begin{tabular}{lcc}
\hline Student & 443 & 82.0 \\
\hline Employed & 91 & 16.9 \\
\hline Unemployed & 6 & 1.1 \\
\hline
\end{tabular}

University major $(n=443)$

Administration / management

\begin{tabular}{lcc}
\hline Administration / management & 10 & 2.3 \\
\hline Biotechnology & 18 & 4.1 \\
\hline Nutrition & 87 & 19.6 \\
\hline Physiotherapy & 140 & 31.6 \\
\hline Cosmetology & 69 & 15.6 \\
\hline Nursing & 44 & 9.9 \\
\hline Obstetrics & 22 & 5.0 \\
\hline Medical emergency services & 18 & 4.1 \\
\hline Other & 35 & 7.8 \\
\hline Year of study (n=443) & & \\
\hline I & 226 & 51.0 \\
\hline II & 120 & 27.1 \\
\hline III & 83 & 18.7 \\
\hline IV & 8 & 1.8 \\
\hline V & 6 & 1.4 \\
\hline
\end{tabular}

$\mathrm{M}$ - mean; $\mathrm{N}$ - number of observations; $\mathrm{SD}=$ standard deviation Source: own elaboration.

\section{RESULTS}

Psychometric characteristics of the Polish version of the MAS Scale. Since different language versions of the MAS yielded different factor structures, analysis of its Polish version commenced with determining the number of individual scales. During the Factor Analysis, 8 factors achieved total loading higher than 1, 3 of them higher than 2. Based on the interpretation of the scree plot (Fig. 1) and the percentage of the explained variance, it was found that, similarly to the original version, the MAS-PL performed a 3 -factor structure, explaining a total of slightly over $45 \%$ of the observed variance. Additional simulations testing the possibility of listing 4 factors (as in the French-language version) [26] or 5 factors (as in the original version) [27] failed, which led to the decision to leave the original 3-factor solution.

The 3-factor model explained a total of $44.754 \%$ of the variance, and further factor solutions increased this percentage only to a slight degree $(<5 \%)$, according to well sample adequacy $[\mathrm{KMO}=0.877$; X2 $(561)=8723.737$; $\mathrm{p}<0,001]$. Factor analysis was supplemented by Varimax rotation with Kaiser normalization for uncorrelated factors, 


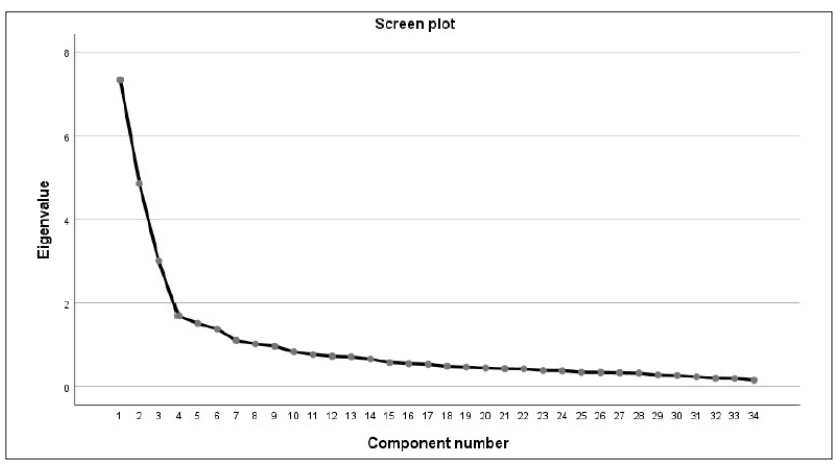

Figure 1. A screen plot yielding a 3-factor MAS-PL structure. Source: own elaboration

exactly the same as the authors of original MAS scale and other adaptations. Correlation between particular factors are presented in a separate Table. This procedure showed that the internal structures of all MAS-PL scales are very similar to the original one. Only 2 items included in the emotional domain loaded more than 1 factor, while the other items had strong $(>0.8)$ to weak $(<0.3)$ factor loadings. The rotated component matrix of the MAS-PL is presented in Table 2. Loadings of negligible strength $(<0.1)$ were hidden to increase readability of results.

Table 2 also contains information about the reliability of individual MAS-PL scales. The entire tool (34 items) was characterized by a very satisfactory reliability $(\alpha=0.875)$. Also, factors measuring individual components of attitudes towards the disabled were characterized by a significant measurement accuracy - each scale achieving a reliability ratio exceeding $\alpha=0.8$. Similar to the original version of the MAS and all its adaptations, a slightly lower reliability was found for the behavioural scale, which, however, may be related to the fact that it is the shortest one (8 items).

Research on the different language versions of the MAS yielded different results regarding correlations between its individual components. Table 3 presents the results of correlation analysis between affective, cognitive and behavioral MAS-PL subscales.

Table 3. Spearman's correlation coefficients between individual MAS scales

\begin{tabular}{lcccc}
\hline & 1 & 2 & 3 & 4 \\
\hline 1) Global MAS & - & & & \\
\hline 2) Affective MAS & $0.827^{* * * *}$ & - & & \\
\hline 3) Cognitive MAS & $0.529^{* * *}$ & $0.128^{* * *}$ & - & - \\
\hline 4) Behavioral MAS & $0.611^{* * *}$ & $0.286^{* * *}$ & $0.217^{* * *}$ & - \\
\hline $\begin{array}{l}* * \\
\text { Source: own elaboration }\end{array}$ & & & &
\end{tabular}

Score distribution in the measurement of attitudes towards the disabled. Table 4 includes information on the results of the pilot study with the use of the MAS-PL. Distribution of the global score was clearly similar to normal distribution, typical for the general population, as evidenced by the insignificant result of the Shapiro-Wilk test. Similarly, distribution of the longest of the subscales, measuring the emotional component of attitudes towards the disabled, can also be regarded as essentially similar to normal distribution. In turn, the other 2 distributions are significantly different from the Gaussian curve $(\mathrm{p}<0.001)$. In the measurement of
Table 2. Principal component factor analyses with Varimax rotation and Cronbach's alpha

\begin{tabular}{|c|c|c|c|}
\hline MAS factors & Affects & Cognitions & Behaviours \\
\hline Stress (emotion 2) & 0.786 & & \\
\hline Upset (emotion 11) & 0.780 & & 0.200 \\
\hline Tension (emotion 1) & 0.774 & & \\
\hline Nervousness (emotion 4) & 0.749 & & \\
\hline Fear (emotion 10) & 0,688 & & 0.115 \\
\hline Shame (emotion 5) & 0.665 & & 0.231 \\
\hline Shyness (emotion 13) & 0.648 & & \\
\hline Helplessness (emotion 3) & 0.645 & & 0.197 \\
\hline Calmess (emotion 8) & -0.633 & -0.272 & \\
\hline Relaxation (emotion 6) & 0.567 & -0.246 & \\
\hline Guilt (emotion 12) & -0.554 & & 0.213 \\
\hline Serenity (emotion 7) & -0.507 & -0.302 & \\
\hline Depression (emotion 9) & 0.490 & & 0.128 \\
\hline Pity (emotion 14) & 0.382 & -0.158 & 0.146 \\
\hline He/she looks friendly. (cognition 4) & & -0.792 & \\
\hline We may get along really well (cognition 3) & & -0.783 & \\
\hline He/she is fine (cognition 2) & & -0.752 & 0.142 \\
\hline $\begin{array}{l}\text { Why not get to know him/her better? } \\
\text { (cognition 9) }\end{array}$ & & -0.715 & \\
\hline $\begin{array}{l}\text { He/she seems to be an interesting boy/girl } \\
\text { (cognition 1) }\end{array}$ & & -0.707 & 0.181 \\
\hline $\begin{array}{l}\text { I can always talk with him/her about things } \\
\text { that interest both of us (cognition 7) }\end{array}$ & & -0.627 & \\
\hline lenjoy meeting new people (cognition 5) & -0.184 & -0.622 & \\
\hline $\begin{array}{l}\text { I can make him/her feel more comfortable } \\
\text { (cognition 8) }\end{array}$ & 0.101 & -0.604 & \\
\hline $\begin{array}{l}\text { He/she will enjoy getting to know me } \\
\text { (cognition 6) }\end{array}$ & & -0.590 & \\
\hline $\begin{array}{l}\text { He/she will appreciate it if / start a conversation } \\
\text { (cognition 10) }\end{array}$ & 0.232 & -0.368 & 0.155 \\
\hline Get up and leave (behaviour 2) & & & 0.826 \\
\hline Find an excuse to leave (behaviour 5) & 0.199 & & 0.754 \\
\hline $\begin{array}{l}\text { Read the newspaper / talk on a cell phone } \\
\text { (behaviour 3) }\end{array}$ & 0.153 & & 0.741 \\
\hline Move away (behaviour 1) & 0.211 & & 0.726 \\
\hline Move to another table (behaviour 6) & & & 0.694 \\
\hline Start a conversation. (behavior 8) & 0.140 & -0.367 & -0.443 \\
\hline $\begin{array}{l}\text { Initiate a conversation if he / she doesn't make } \\
\text { the first move (behaviour } 7 \text { ) }\end{array}$ & 0.152 & -0.367 & $-0,417$ \\
\hline Disgust (emotion 15) & 0,353 & & 0,395 \\
\hline Continue what he / she was doing (behaviour 4) & 0.155 & & 0.314 \\
\hline Alertness (emotion 16) & 0.195 & -0.123 & 0.223 \\
\hline$\%$ of explained variance & 18.493 & 14.906 & 3.860 \\
\hline Reliability & $\underline{0.886}$ & $\underline{0.860}$ & $\underline{0.807}$ \\
\hline
\end{tabular}

Source: own elaboration

the cognitive component, a higher frequency was observed of average results in relation to extreme ones, while in the measurement of behavurs towards the disabled, there were numerous disproportions in the frequency of individual score categories.

The MAS-PL turned out to be related to some sociodemographic factors. In the behavioural scale, men achieved 
Table 4. Basic distribution of results in the MAS-PL $(N=540)$

\begin{tabular}{lccccccc}
\hline MAS & $\begin{array}{c}\text { Possibile } \\
\text { range }\end{array}$ & $\begin{array}{c}\text { Min.- } \\
\text { Max. }\end{array}$ & M & SD & Skewness & Kurtosis & S-W test \\
\hline Global score & $34-170$ & $36-123$ & 80.90 & 15.64 & -0.025 & -0.262 & 0.605 \\
\hline Affective & $16-80$ & $16-70$ & 40.22 & 10.82 & 0.157 & -0.435 & 0.006 \\
\hline Cognitive & $10-50$ & $10-50$ & 22.85 & 6.07 & 0.267 & 0.660 & $<0.001$ \\
\hline Behavioral & $8-40$ & $8-36$ & 17.84 & 5.39 & 0.426 & -0.156 & $<0.001$ \\
\hline
\end{tabular}

M - mean; SD - standard deviation; S-W test - Shapiro-Wilk's test of normality Source: own elaboration

significantly more points, by an average of 1.46 points $(Z$ $=-2.185 ; \mathrm{p}=0.026)$, while women tended to have a higher emotional component (on average by 2.57 points, $\mathrm{Z}=-1.729$; $\mathrm{p}=0.084$ ). Intensity of the emotional component decreased slightly with age $(\mathrm{rho}=-0.079 ; \mathrm{p}=0.071)$, while the intensity of the cognitive component increased ( $\mathrm{rho}=0.077 ; \mathrm{p}=0.078$ ). A lower level of education was also conducive to weaker emotional reactions ( $r h o=-0.099 ; \mathrm{p}=0.021)$. On the other hand, the size of the place of residence was not associated with any dimension of the MAS. Working people and students did not differ from each other, neither in the overall result nor in individual subscales.

\section{DISCUSSION}

The aim of this study was to conduct cultural adaptation of the MAS for the Polish population and to examine its factor structure, reliability and links between attitude and socio-demographic factors, such as: age, gender and place of residence. The Polish version of the MAS was characterized by a similar factor structure as the original MAS from 2007 [13], including 3 subscales (affect, cognition, behaviour) and 34 items, and a satisfactory reliability. The obtained results suggest that the MAS-PL can be used to assess attitudes towards PWD in Poland, which can then be compared with international data collected in research with the use of the MAS scale [26, 28-36].

In the majority of population studies, the other language versions showed the same factor structure - i.e. 3 internally consistent and mutually independent factors, corresponding to the 3 components of an attitude. Some studies, however, suggested the possibility of a different approach to the MAS domains, e.g. the identification of 4 factors, including division of the emotional aspect into positive and negative affect.

The 3-subscale MAS adaptation was successfully conducted in the Serbian [29], Korean [33] and Turkish [34] samples. However, some adaptations [e.g. 29] introduced language changes, consisting in adding, deleting or changing various items. For instance, in the Serbian MAS, 2 subscales for each factor were finally distinguished, including their positive and negative aspects in the following manner: affects (negative emotion, but potentially positive/strong negative emotions), cognitions (positive / perplexing), behaviours (avoiding / approaching).

A 4-dimensional MAS (negative affect, calm, positive cognition, behavioural avoidance) with modified items was first introduced in the Spanish version in 2013 [31-30 items], then implemented in the French version in 2015 [26 -20 items], and the German version in 2018 [35-16 items]. In recent studies, researchers using Confirmatory Factor Analysis demonstrated a better fit of the 4-factor model
(Comparative Fit Index CFI>.95) [35]. However, studies on the Polish3- factor model showed that each scale achieved a reliability coefficient exceeding $\alpha=0.8$, and the addition of subsequent sub-scales failed to yield satisfactory effects. Similar results were reported with the Turkish scale [34]. The internal consistency coefficient for the entire Turkish version of the MAS was $\alpha=0.90$, which was not reported even for the original scale [13]. Similar findings were described by Lunde and Seekins in their study with the use of the original MAS on a sample of young Americans [32], and in a study by Banks [28]. A comprehensive comparison of the reliability measures of the different language versions of the MAS are presented in Table 5 .

Table 5. Internal consistency (Cronbach's alpha) for a three-factor MAS structure by different authors

\begin{tabular}{|c|c|c|c|c|c|c|}
\hline \multirow{2}{*}{$\begin{array}{l}\text { MAS, } \\
\text { number } \\
\text { of items }\end{array}$} & \multirow{2}{*}{$\begin{array}{l}\text { Authors, } \\
\text { year }\end{array}$} & \multirow{2}{*}{ Sample } & \multicolumn{3}{|c|}{ MAS Factors } & \multirow{2}{*}{ Total } \\
\hline & & & Affects & Cognitions & Behaviors & \\
\hline $\begin{array}{l}\text { Original } \\
\text { MAS, } \\
34 \text { items }\end{array}$ & $\begin{array}{l}\text { Findler et } \\
\text { al. } 2007\end{array}$ & $\begin{array}{l}132 \text { Jewish } \\
\text { Israelis }\end{array}$ & 0.90 & 0.88 & 0.83 & - \\
\hline $\begin{array}{l}\text { Turkish } \\
\text { MAS, } \\
34 \text { items }\end{array}$ & $\begin{array}{l}\text { Yelpaze } \\
\text { and } \\
\text { Türküm } \\
2018\end{array}$ & $\begin{array}{l}165 \text { Turkish } \\
\text { university } \\
\text { students }\end{array}$ & 0.88 & 0.89 & 0.84 & 0.90 \\
\hline $\begin{array}{l}\text { Korean } \\
\text { MAS-K, } \\
34 \text { items }\end{array}$ & $\begin{array}{l}\text { Kim et al. } \\
2015\end{array}$ & $\begin{array}{l}213 \text { South } \\
\text { Korean } \\
\text { undergraduate } \\
\text { participants }\end{array}$ & 0.87 & 0.88 & 0.84 & - \\
\hline $\begin{array}{l}\text { English } \\
\text { MAS, } \\
34 \text { items }\end{array}$ & $\begin{array}{l}\text { Lunde and } \\
\text { Seekins } \\
2014\end{array}$ & $\begin{array}{l}50 \text { American } \\
\text { college } \\
\text { students (USA) }\end{array}$ & 0.876 & 0.892 & 0.792 & 0.91 \\
\hline $\begin{array}{l}\text { English } \\
\text { MAS, } \\
34 \text { items }\end{array}$ & $\begin{array}{l}\text { Banks } \\
2008\end{array}$ & $\begin{array}{l}140 \text { American } \\
\text { college } \\
\text { students (USA) }\end{array}$ & 0.88 & 0.89 & 0.83 & 0.91 \\
\hline $\begin{array}{l}\text { Polish } \\
\text { MAS-PL, } \\
34 \text { items }\end{array}$ & & $\begin{array}{l}408 \text { Polish } \\
\text { medical } \\
\text { university } \\
\text { students }\end{array}$ & 0,870 & 0,853 & 0,810 & 0,869 \\
\hline
\end{tabular}

Source: own elaboration

To date, there have been 2 attempts to adapt the MAS to measure attitudes towards a particular disability. In French research, the 4-factor model applied to measure attitudes towards people with autism, demonstrated satisfactory internal consistency for the entire scale $(\alpha=0.79)$ and for individual factors (negative affects $\alpha=0.74$, calm $\alpha=0.86$, cognitions $\alpha=0.76$, behaviours $\alpha=0.91$ ). In Dutch research [34], an attempt was made to apply a 3-factor model to assess attitudes towards deaf, blind, paralyzed or intellectually disabled persons. As a result, a separate questionnaire was created for each disability. As there was no clear factor structure that would apply to all 4 types of disability, no further analysis of the MAS questionnaire was carried out.

In 2 studies (on the Korean and Ethiopian samples), apart from the MAS scale, the Marlowe-Crowne Social Desirability Scale (MCSDS) was used to assess the level of social desirability [37]. A study by Getachew [30] on a sample of Ethiopian college students suggested that the respondents did not tend to react in a socially desirable way by expressing negative attitudes towards the disabled. However, this was due to the fact that such attitudes were not culturally disapproved, and, what is more, the respondents did not feel the need to 
be socially accepted - presumably due to the elitism of the student status in Ethiopia. In contrast, Korean studies showed a confounding, significant influence of the level of social desirability on the affective and cognitive domains of the MAS-K. The semi-correlations (sr) between social desirability and the cognitive domain ( $\mathrm{sr}=-.202, \mathrm{p}<.001$ ), as well as the affective domain $(\mathrm{sr}=-.242, \mathrm{p}=.002)$ in the MAS were significant and in the negative direction. Therefore, it was recognized that social desirability may influence attitudes towards disabled people, or their particular domains.

In this study, as in the case of most studies using the MAS, including the originversion, the level of social desirability was not examined. Still, the structure of the MAS uses the mechanism of projection to avoid dishonest responses - the respondent is asked to assess how an abstract character (and not him or herself) feels, thinks and behaves in contact with PWD, thus projecting his or her own mental states.

The MAS scale is an excellent tool used by researchers to perform preliminary and final evaluation of the effectiveness of educational programmes, including training or social policy programmes. For example, the MAS scale was used in research 'college students perceptions on effects of volunteering with adults with developmental disabilities'. The results found significant positive changes in the attitudes of students [38]. In turn, to examine the effectiveness of disability awareness training (DAT), the Spanish MAS was used (preand post-DAT). There were significant positive changes in 2 of 4 MAS constructs: emotion $\mathrm{p}=.005$ and cognition $\mathrm{p}$ $=.003$ [17] Other studies on the Gamified Disability Awareness Programme on the Peers' Disability showed significant positive changes in factors of the Korean version of the MAS scale (applied before and after the programme) [39].

Limitations of the study. In the current study, the majority of the study group were students. In the original MAS study, as well as in most of the other adaptations and other research with the MAS scale, the majority of participants were also students (Tab. 5).

In the current study, the vast majority of students studied medical fields, of which about 25\% were physiotherapy students who may have slightly different opinions than other people due to the specificity of their work (helping patients, including those with disabilities), and their possible earlier contact with people with disabilities during their studies. However, there were no significant differences between students and employees, which may suggest that medical students are not a particularly sensitive group.

In the present study, the majority of respondents were women, which, according to research, usually results in more positive attitudes towards people with various disabilities $[27,40,41]$. However, there are studies in which men declared more positive attitudes regarding knowledge of the capacity and rights factors [42]. In the current study, no significant relationships were found between the MAS scale and selected socio-demographic factors. However, weak tendencies indicated slightly more negative attitudes in men. In contrast, women were characterized by a more positive attitude towards people with disabilities.

In addition, the presented sample included mostly young people, which, according to different studies, may result in more positive [40], negative $[13,36]$ or neutral attitudes towards the disabled - i.e. young age does not clearly influence these attitudes $[33,43]$. In this study, no significant association was observed between age and the MAS score, except for a slight positive tendency suggesting a (still non-significant) link between the cognitive domain and age, which probably stems from educational progress or accumulated experience. In view of that, and due to increased research and educational opportunities, researchers tend to focus on investigating young people's attitudes [28, 30-35].

Following Kim et al. [33], it should be stressed that sociodemographic factors, especially those related to gender and past contact, may not necessarily be the most significant ones in shaping people's attitudes towards the disabled. In addition, attaching great importance to demographic variables may lead to stereotyping of respondents, and thus distorting research results or educational initiatives.

A slight limitation may also be the fact that the validity of the Polish version of the MAS was not verified in an empirical way. This was dictated by a lack of tools that could be used to check its convergent or divergent validity, and the fact that none of the reported population studies questioned the tool's validity. What is more, the essential criteria of goodness (copying the original structure and achieving significant measurement reliability) suggested that the MAS-PL was a valid and reliable tool to accurately differentiate the attitudes of the subjects.

\section{CONCLUSIONS}

The Polish version of the MAS scale (MAS-PL) has been developed and presented as a reliable instrument for studying the attitudes of Poles towards people with disabilities. The scale can be used as a preliminary assessment tool when creating educational programmes, including those for training and social policy, as well as assessing the effectiveness of the programmes. Studies using the MAS-PL will allow comparisons of research findings conducted with the use of MAS scales in other English-speaking (original/English MAS) or Spanish-speaking (Spanish MAS) populations and German (G-MAS), Korean (MAS-K), Serbian (Serbian MAS), Turkish (Turkish MAS) and French populations (French MAS autism).

\section{Declaration of interest statement}

The authors declare that they have no competing interests.

\section{Acknowledgments}

The authors of this study express their thanks to Liora Findler, Noa Vilchinsky and Shirley Werner, the authors of the MAS Scale, for their kindness in research and permission to adapt the scale.

\section{REFERENCES}

1. Mahler F. Maldevelopment and Marginality, in: Danecki J (red.) Insights into Maldevelopment, Warsaw (Poland): University of Warsaw; 1996: 193.

2. Livneh H. On the origins of negative attitudes towards people with disabilities. Rehabilitation literature. 1982; 43(11-12): 338-347.

3. World Health Organization. World Report on Disability [Internet]. Geneva: WHO Press; 2011 [cited 2019 Feb 14]. Available from: http:// www.who.int/disabilities/world_report/2011/accessible_en.pdf

4. Central Statistical Office. Rocznik Demograficzny 2013 [Demographic Yearbook of Poland] [Internet]. Warsaw [Poland]: Statistical Publishing Establishment; 2013 [cited 2019 Feb 14]. Available from: http://stat.gov.

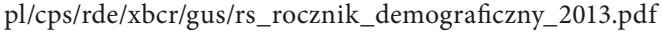


5. Hunt P, editor. Stigma: The experience of Disability. London-DublinMelbourne: Geoffrey Chapman; 1966: 145-149.

6. Kruger L, editor. Pain and touch. San Diego (CA): Academic Press; 1996. Mark BS, Incorvaia J, editors. The handbook of infant, child, and adolescent psychotherapy. Northvale (NJ): Jason Aronson Inc.; 1995-1997.

7. Bowe F. Handicapping America: Barriers to disabled people. New York (NY): Harper \& Row; 1978.

8. Radlińska IA, Ocena prawa i polityki wobec osób niepełnosprawnych intelektualnie w stopniu umiarkowanym [Assessment of law and policy on people with moderate intellectual disability]. [dissertation] Szczecin: Pomeranian Medical University in Szczecin; 2016. Polish.

9. Olivier M. The Politics of Disablement. Basingstoke: Macmillan; 1990.

10. Olivier M. Understanding Disability: From Theory to Practise. Basingstoke: Macmillan; 1996.

11. United Nations General Assembly. The Standard Rules on the Equalization of Opportunities for Persons with Disabilities with 20 December 1993. New York:UN; 1994. Resolution 48/96.

12. United Nations General Assembly. Convention on the Rights of Persons with Disabilities with 13 December 2006, New York:UN; 2006. Resolution 61/106.

13. Findler L, Vilchinsky N, Werner S. The Multidimensional Attitudes Scale Toward Persons With Disabilities (MAS) Construction and Validation, Rehabilitation Counseling Bulletin. Rehabil Couns Bull. 2007; 50(3): 166-176.

14. Petty RE. Attitudes and persuasion: Classic and contemporary approaches. Routledge. 2018: 5-6.

15. Wolska-Zogata I. Social attitudes towards the disabled-review of research. Współczesne Pielęgniarstwo i Ochrona Zdrowia. 2012; 1(4): 81-87. Polish.

16. Tan BS, Wilson E, Campain R et al. Understanding Negative Attitudes Toward Disability to Foster Social Inclusion: An Australian Case Study. In Inclusion, Equity and Access for Individuals with Disabilities. Palgrave Macmillan, Singapore. 2019: 41-65.

17. Hayward L, Fragala-Pinkham M, Schneider J, et al. Examination of the short-term impact of a disability awareness training on attitudes toward people with disabilities: A community-based participatory evaluation approach. Physiotherapy Theory and Practice. 2019: 1-14.

18. Sahin H, Akyol A. D. Evaluation of nursing and medical students attitudes towards people with disabilities. J Clin Nurs. 2010; 19(15-16): 2271-2279.

19. Antonak RF, Livneh H. Measurement of attitudes towards persons with disabilities. Disabil Rehabil. 2000; 22(5): 211-224.

20. Lam WY, Gunukula SK, McGuigan D, et al. Validated instruments used to measure attitudes of healthcare students and professionals towards patients with physical disability: a systematic review. J Neuroeng Rehabil. 2010; 7(1): 55. Online Early

https://www.ncbi.nlm.nih.gov/pmc/articles/PMC2987969/ (access: 2019.10.15).

21. Martin AR, Arregui EA. Development and validation of a scale to identify attitudes towards disability in Higher Education. Psicothema. 2013; 25(3): 370-376.

22. Satchidanand N, Gunukula SK, Lam WY, et al. Attitudes of healthcare students and professionals toward patients with physical disability: a systematic review. Am J Phys Med Rehabil. 2012; 91(6): 533-545.

23. Palad YY, Barquia RB, Domingo HC, et al. Scoping review of instruments measuring attitudes toward disability. Disabil Health J. 2016;9(3): 354-374.

24. Yuker HE, Block JR, Young JH. The measurement of attitudes toward disabled persons. Albertson, NY: Human Resources Center, 1966.
25. Rosenberg MJ, Hovland CI, editors. Attitude organization and change: An analysis of consistency among attitude components. Oxford (England): Yale University Press; 1966.

26. Dachez J, Ndobo A, Ameline A. French validation of the multidimensional attitude scale toward persons with disabilities (MAS): the case of attitudes toward autism and their moderating factors. J Autism Dev Disord. 2015; 45(8): 2508-2518.

27. Vilchinsky N, Werner S, Findler L. Gender and attitudes toward people using wheelchairs: A multidimensional perspective. Rehabil Couns Bull. 2010; 53(3): 163-174.

28. Banks CM. Creating positive attitudes toward people with disabilities through inclusion. [dissertation]. Hanover (IN): Hanover College; 2008.

29. Dragojević N, Milačić-Vidojević I, Hanak N. Attitudes Toward People With Physical Disabilities, their structure and correlating variables. Special education and rehabilitation science and/or practice. 2010: 29-51.

30. Getachew AT. Attitudes of Ethiopian college students toward people with visible disabilities. [dissertation]. Iowa City (Iowa): University of Iowa; 2011.

31. Stevens LF, Getachew MA, Perrin PB, et al. Factor analysis of the Spanish Multidimensional Attitudes Scale Toward Persons with Disabilities. Rehabil Psychol. 2013; 58(4): 396-404.

32. Lund EM; Seekins T. Early Exposure to People with Physical and Sensory Disabilities and Later Attitudes toward Social Interactions and Inclusion. Physical Disabilities: Education and Related Services. 2014; 33(1): 1-16.

33. Kim KH, Lu J; Estrada-Hernandez N. Attitudes toward people with disabilities: The tripartite model, social desirability, and other controversial variables. JAPC. 2015; 5(1): 23-37.

34. Yelpaze İ; Türküm AS. Adaptation and Validation of Turkey Version of Multidimensional Attitudes toward Persons with Disabilities. OPUSInternational Journal of Society Researches. 2018; 8(14): 167-187 Online https://toad.edam.com.tr/sites/default/files/pdf/engellilere-yonelikcok-boyutlu-tutum-olcegi-toad.pdf (access: 2019.02.28).

35. Wöhrle J, Franke S, Kissgen R. The German Multidimensional Attitude Scale Toward Persons With Disabilities (G-MAS): A factor analytical study among high-school students. Rehabil Psychol. 2018; 63(1): 83-91.

36. De laat S; Freriksen E; Vervloed MPJ. Attitudes of children and adolescents toward persons who are deaf, blind, paralyzed or intellectually disabled. Res Dev Disabil. 2013; 34(2): 855-863.

37. Crowne DP, Marlowe D. A new scale of social desirability independent of psychopathology. J Consult Psychol. 1960; 24: 349-354.

38. Kropp JJ, Wolfe BD. College Students' Perceptions on Effects of Volunteering with Adults with Developmental Disabilities. Journal of Higher Education Outreach and Engagement. 2018; 22(3): 93-118.

39. Kwon J. Effects of Gamified Disability Awareness Program on the Peers' Disability. Journal of Korea Game Society. 2019; 19(2): 45-54.

40. Goreczny AJ, Bender EE, Caruso G, Feinstein CS. Attitudes toward individuals with disabilities: Results of a recent survey and implications of those results. Res Dev Disabil. 2011; 32(5): 1596-1609.

41. Hampton N, Zhu Y. Gender, culture, and attitudes toward people with psychiatric disabilities. Journal of Applied Rehabilitation Counseling. 2011; 42(3): 12-19.

42. Morin DD, Rivard MM, Crocker AG, Boursier CP, Caron JJ. Public attitudes towards intellectual disability: A multidimensional perspective. J Intellect Disabil Res. 2013; 57(3): 279-292.

43. Li C, Tsoi ES, Wang JK. Chinese college students attitudes toward people with intellectual disabilities: Differences by study major, gender, contact, and knowledge. Int J Dev Disabil. 2012; 58(3): 137-144. 


\section{Appendix}

\section{Wielowymiarowa skala postaw względem osób niepelnosprawnych (MAS-PL)}

Winieta: "Wyobraź sobie następującą sytuację: Adam/Ewa wyszedł(ła) na lunch z przyjaciółmi do kawiarni. Osoba (mężczyzna/kobieta) na wózku inwalidzkim, $\mathrm{z}$ którym Adam/Ewa nie jest zaznajomiony(ona), wchodzi do kawiarni i dołącza do grupy. Adam/Ewa jest przedstawiony tej osobie. Wkrótce potem wszyscy wychodzą, a jedynie Adam/Ewa i osoba na wózku inwalidzkim pozostają razem przy stole. Adam/Ewa ma 15 minut czekać na odjazd tej osoby. Spróbuj wyobrazić sobie tę sytuację."

Ludzie, którzy uczestniczą w takiej sytuacji, doświadczają różnych emocji. Poniżej znajduje się lista możliwych emocji, które mogą powstać przed, w trakcie i/lub po takiej sytuacji. Oceń w każdej linii prawdopodobieństwo, że ta emocja może pojawić się u Adama/Ewy.

\begin{tabular}{llllll}
\hline & \multicolumn{4}{c}{$\begin{array}{c}\text { Stopień } \\
\text { prawdopodobieństwa }\end{array}$} \\
\hline Wmocja & Wcale & & \multicolumn{3}{c}{$\begin{array}{c}\text { Bardzo } \\
\text { silna }\end{array}$} \\
\hline 1. Napięcie & 1 & 2 & 3 & 4 & 5 \\
\hline 2. Stres & 1 & 2 & 3 & 4 & 5 \\
\hline 3. Bez radność & 1 & 2 & 3 & 4 & 5 \\
\hline 4. Nerwowość & 1 & 2 & 3 & 4 & 5 \\
\hline 5. Zawstydzenie & 1 & 2 & 3 & 4 & 5 \\
\hline 6. Odprężenie & 1 & 2 & 3 & 4 & 5 \\
\hline 7. Pogodność & 1 & 2 & 3 & 4 & 5 \\
\hline 8. Spokój & 1 & 2 & 3 & 4 & 5 \\
\hline 9. Smutek/Przygnębienie & 1 & 2 & 3 & 4 & 5 \\
\hline 10. Lęk & 1 & 2 & 3 & 4 & 5 \\
\hline 11. Zdenerwowanie/Zaniepokojenie & 1 & 2 & 3 & 4 & 5 \\
\hline 12. Poczucie winy & 1 & 2 & 3 & 4 & 5 \\
\hline 13. Onieśmielenie & 1 & 2 & 3 & 4 & 5 \\
\hline 14. Współczucie & 1 & 2 & 3 & 4 & 5 \\
\hline 15. Obrzydzenie & 1 & 2 & 3 & 4 & 5 \\
\hline 16. Czujność & 1 & 2 & 3 & 4 & 5 \\
\hline
\end{tabular}

Ludzie, którzy biorą udział w takiej sytuacji, doświadczają różnorodnych myśli. Poniżej znajduje się lista możliwych myśli, które mogą powstać przed, w trakcie i/lub po takiej sytuacji. Oceń w każdej linii prawdopodobieństwo, że te myśli mogą się pojawić u Adama/Ewy wobec osoby na wózku inwalidzkim.

\begin{tabular}{|c|c|c|c|c|c|c|}
\hline \multirow{2}{*}{\multicolumn{2}{|c|}{ Przekonanie/Myśl }} & \multicolumn{5}{|c|}{ Stopień prawdopodobieństwa } \\
\hline & & \multicolumn{3}{|c|}{ Wcale } & & Bardzo silne(a) \\
\hline 1. & On/ona wydaje się być interesującą osobą. & 1 & 2 & 3 & 4 & 5 \\
\hline 2. & On/ona wygląda na osobę w porządku. & 1 & 2 & 3 & 4 & 5 \\
\hline 3. & Możemy się dobrze dogadać. & 1 & 2 & 3 & 4 & 5 \\
\hline 4. & On/ona wygląda przyjaźnie. & 1 & 2 & 3 & 4 & 5 \\
\hline 5. & Lubię poznawać nowych ludzi. & 1 & 2 & 3 & 4 & 5 \\
\hline 6. & Będzie jemu/jej miło poznać mnie. & 1 & 2 & 3 & 4 & 5 \\
\hline 7. & $\begin{array}{l}\text { Zawsze mogę z nim/nią porozmawiać o rzeczach, } \\
\text { którymi oboje się interesujemy. }\end{array}$ & 1 & 2 & 3 & 4 & 5 \\
\hline 8. & $\begin{array}{l}\text { Mogę sprawić, że on/ona czuje się bardziej } \\
\text { komfortowo. }\end{array}$ & 1 & 2 & 3 & 4 & 5 \\
\hline 9. & Dlaczego nie poznać jego/jej lepiej? & 1 & 2 & 3 & 4 & 5 \\
\hline 10. & $\begin{array}{l}\text { On/ona będzie wdzięczny(a), jeśli rozpocznę } \\
\text { rozmowę. }\end{array}$ & 1 & 2 & 3 & 4 & 5 \\
\hline
\end{tabular}

Ludzie różnie się zachowują, gdy uczestniczą w takiej sytuacji. Poniżej znajduje się lista możliwych zachowań, które mogą mieć miejsce przed, w trakcie i/lub po takiej sytuacji. Oceń w każdej linii prawdopodobieństwo, że Adam/Ewa zachowaliby się w następujący sposób:

\begin{tabular}{|c|c|c|c|c|c|c|}
\hline \multirow{2}{*}{\multicolumn{2}{|c|}{ Zachowanie }} & \multicolumn{5}{|c|}{ Stopień prawdopodobieństwa } \\
\hline & & Wcale & & & & Bardzo silne \\
\hline 1. & Odsunie się & 1 & 2 & 3 & 4 & 5 \\
\hline 2. & Wstanie i wyjdzie & 1 & 2 & 3 & 4 & 5 \\
\hline 3. & Czyta gazetę lub rozmawia przez telefon & 1 & 2 & 3 & 4 & 5 \\
\hline 4. & Kontynuuje to, co robił/robiła & 1 & 2 & 3 & 4 & 5 \\
\hline 5. & Znajdzie wymówkę, aby wyjść & 1 & 2 & 3 & 4 & 5 \\
\hline 6. & Przesiądzie się do innego stołu & 1 & 2 & 3 & 4 & 5 \\
\hline 7. & $\begin{array}{l}\text { Zainicjuje rozmowę, jeśli on/ona nie wykona pierwszego } \\
\text { kroku }\end{array}$ & 1 & 2 & 3 & 4 & 5 \\
\hline 8. & Rozpocznie konwersację & 1 & 2 & 3 & 4 & 5 \\
\hline
\end{tabular}

